\title{
The role of biogenic processes in extraction of Ce during laterite weathering at Mount Weld REE deposit, Western Australia
}

\author{
IRINA A ZHUKOVA ${ }^{1}$, ALEKSANDR SASHA STEPANOV ${ }^{1}$, \\ SHAO-YONG JIANG ${ }^{2}$, ANDREY V KORSAKOV ${ }^{3}$, DAVID T \\ MURPHY $^{4}$ AND RALPH BOTTRILL ${ }^{5}$ \\ ${ }^{1}$ China University of Geosciences, Wuhan \\ ${ }^{2}$ China University of Geosciences \\ ${ }^{3}$ V.S. Sobolev Institute of Geology and Mineralogy of the \\ Siberian Branch of the RAS \\ ${ }^{4}$ Queensland University of Technology \\ ${ }^{5}$ Mineral Resources Tasmania \\ Presenting Author: irina.a.zhukova@gmail.com
}

Mount Weld, one of world's richest REE deposits, is located in a weathered laterite cap of carbonatite $[1,2]$. The laterite samples show $\mathrm{REE}_{2} \mathrm{O}_{3}$ content reaching 51.8 wt. \% representing rocks with some of the highest REE content known to date. A special characteristic of Mount Weld laterite is the presence of intense negative $\mathrm{Ce}$ anomaly on chondrite normalised $\mathrm{REE}$ patterns $\left(\mathrm{Ce}_{\mathrm{CN}} / \mathrm{Ce}^{*}=0.68\right.$; where $\mathrm{Ce} *=\operatorname{sqrt}\left(\mathrm{La}_{\mathrm{CN}} * \operatorname{Pr}_{\mathrm{CN}}\right)$. At the mineral level, the anomaly varies significantly: it is absent in partly corroded primary monazite $(\sim 1)$, while the supergene minerals florencite-(Ce) and rhabdophane-(Nd) demonstrate prominent $\mathrm{Ce}$ anomalies ( 0.6 and 0.2 respectively). An interesting feature of Mount Weld laterite is a presence of tubelike structures interpreted as paleo-plants that are composed of rhabdophane-(Nd).

Negative Ce anomaly is sometimes observed in carbonatite laterites [3]. Specific organic compounds could create conditions for fractionation of $\mathrm{Ce}$ from other REE at relatively reduced conditions $[4,5]$. Therefore, in Mount Weld, the plant-mediated wreathing could have created conditions for extraction of Ce.

On the other hand, the solubility of Ce increases in alkaline waters of lakes where positive $\mathrm{Ce}$ anomalies have been sometimes observed [6]. The occurrence of lacustrine sediments above Mount Weld laterite suggest that the existence of a lake in the past and the loss of $\mathrm{Ce}$ to lake waters could be another mechanism for formation of the intense Ce anomalies in Mount Weld laterite. In both scenarios, the redistribution of $\mathrm{Ce}$ in the Mount Weld weathering profile occurred in a much wetter climate than at present.

[1] Willett, Duncan \& Rankin (1986), Int. Kimberl. Conf. Ext. Abstr. 4, 97-99.

[2] Lottermoser (1990) LITHOS 24, 151-167.

[3] Andersen, Clark, Larson \& Donovan (2017) Ore Geol. Rev. 89, 780-807.

[4] Bau, Tepe \& Mohwinkel (2013) Earth Planet. Sci. Lett. 364, 30-36.

[5] Kraemer, Tepe, Pourret \& Bau (2017) Geochim. Cosmochim. Acta196, 197-208.

[6] Johannesson \& Lyons (1994) Limnol. Oceanogr. 39, 11411154. 